\title{
Design of biogas digester with thermophilic pretreatment for reducing fruits wastes
}

\author{
Budy Rahmat $^{1} \cdot$ Ida Hodiyah $^{1} \cdot$ Apip Supriadi ${ }^{2} \cdot$ Memet Hikmat $^{1} \cdot$ Gilang Purnama $^{1}$
}

Received: 6 August 2018 / Accepted: 19 September 2019 / Published online: 1 October 2019

(c) The Author(s) 2019

\begin{abstract}
Purpose This study aimed to design a biogas digester that works thermophilically and mesophilically and tested its performance to produce biogas and digestate.

Methods This study used some experimental methods, which consists of: (1) design and construction process of the digester which can facilitate the thermophilic process as a pretreatment of the feedstock and the anaerobic digestion process of the substrate; (2) determination of the quantity of biogas, liquid digestate, and compost; and (3) testing digestate quality as a liquid organic fertilizer for Ipomoea reptans.

Results The built biogas digester was able to accommodate thermophilic digestion that runs intensely in the pretreatment tank, where the complex organic compounds, namely cellulose and hemicellulose, decomposed intensively, so that it becomes a suitable substrate. As raw material, every $4 \mathrm{~kg}$ of banana waste, can produce biogas, digestate and dry compost of $10,200 \mathrm{~cm}^{3}$ (highest yield), $5900 \mathrm{~mL}$, and $1420 \mathrm{~g}$, respectively. The highest Ipomoea reptans growth was achieved by digestate treatment from banana waste.

Conclusions Thermophilic pretreatment could shorten the processing time to 3 days. Digestate treatment as a liquid organic fertilizer is able to provide a better supply of nutrients for plants.
\end{abstract}

Keywords Digester design $\cdot$ Fruit wastes $\cdot$ Liquid organic fertilizer $\cdot$ Thermophilic pretreatment

\section{Introduction}

The handling of waste must begin to be realized as part of all citizens' responsibility, so that the conventional handling waste "throw-take-carry-pile" is not justified. This method often leads to accumulation problems if the number of employee and fleets was inadequate, so this method has to be improved and even replaced (Indonesian Government Regulation Number 81 of 2012). Biogas technology is a waste processing technology that has several advantages, such as it can be applied in each location and without forming a by-product. This technology can prevent environmental problems that commonly occur in open dumping and centralized processing. A broad landfill area can be used

Budy Rahmat

budy_unsil@yahoo.com

1 Faculty of Agriculture, Siliwangi University, Tasikmalaya 46115, Indonesia

2 Faculty of Economics and Business, Siliwangi University, Tasikmalaya 46115, Indonesia for more productive activities. This process will lead to sustainable and balanced production of organic fertilizer for soil applications, which will increase yields and improve soil health and environmental quality. The method can be a model of waste processing that can be replicated, especially for developing countries (Sudharmaidevi et al. 2017).

Organic waste is a valuable resource for fertilizer, compost, and fuel. Organic waste is a valuable source of fertilizer, compost and fuel. This biogas production with anaerobic digestion also leaves organic residues in the form of digestate and compost that are rich in nutrients. The use of biogas fuel compared to fossil fuels will reduce the carbon footprint. If these digestates are applied in crop production, the available nutrients which already exist in the nutrient cycle will be recycled and the sustainability of the biogas production process will increase. The use of organic fertilizer also contributes to maintaining and/or improving soil quality (Sogn et al. 2018).

The food waste is assumed to be shredded, sieved and then sent to a digestion tank. The output of this biological process is two valuable products: biogas which may be used 
for either heat or power generation; and digestate that may be utilized as a soil fertiliser (Salemdeeb et al. 2018).

The waste management in Indonesia has been changed by reducing the source and recycling approach of materials, namely $3 R$ (reuse, recycle, reduction). Therefore, all citizens are expected to change the way they view and treat waste as an alternative resource, which can be used optimally or over-used and recycled (Indonesian National Legislation Number 18 of 2008 2008). Furthermore, Indonesian Government Regulation Number 81 of 2012 provides that waste management consists of five stages: segregation, collection, transportation, processing and final processing of waste by all citizens. The rules are applied gradually, planned, and based on clear policies and strategies.

Temperature is one of the most important factors in the succession of composting micro-organisms, and it is relatively easy to ascertain the microbial succession from mesophiles to thermophiles, or conversely from thermophiles to mesophiles, using different incubation temperatures with, for example, the dilution plating method (Nakasaki et al. 2005).

The advantage of using the thermophilic enzymes for conducting biotechnological processes at elevated temperatures are: reducing the risk of contamination by mesophilic microorganisms; decreasing the viscosity of the reaction medium; increasing the bioavailability and solubility of organic compounds; increasing the diffusion coefficient of substrates and products resulting in higher reaction rates (Gomes et al. 2016).

The creative idea of the research offered was to construct a digester that could guarantee the bacteria consortium to effectively work on thermophilic process of $55-60{ }^{\circ} \mathrm{C}$ as a pretreatment action against complex organic matter, such as in fruit wastes, so it became a ready feedstock for the anaerobic digestion process, which generates biogas and digestate.

\section{Materials and methods}

\section{Digester design}

Design a digester that can guarantee: (1) a consortium of microbes working thermophilic $\left(55-60{ }^{\circ} \mathrm{C}\right)$ in the predigester tank; and (2) the microbial consortium works with anaerobic digestion (methanogenesis) in the main digester tank.

The understanding of the design process is important both to manage the design activity and to aid the improvement of products and the overall efficiency of engineering-based companies; it is also the foundation on which a lot of design research is based. It is suggested that understanding this process relative to the creative process will give insight into where and when resources should be focused to enhance creative performance and also the resulting 'quality' of the product designed (Howard et al. 2008). The designers generally worked in sequence according to these stages, but it was not impossible that they returned to a previous step if there were mistakes (Rahmat et al. 2013). The stages of the study are shown in Fig. 1.

The digester testing consisted of two experimental stages, namely: (1) determining the digester capacity that included production of biogas, digestate, and compost; and (2) determining the digestate quality as an organic fertilizer.

\section{Digester testing}

\section{Materials}

Preparation of fruit waste. Banana and papaya wastes were collected from five different waste ponds (10 kg each) as samples representing the Cilembang vegetable market, Tasikmalaya, Indonesia. The waste is mixed homogeneously and then crushed with an electric blender.

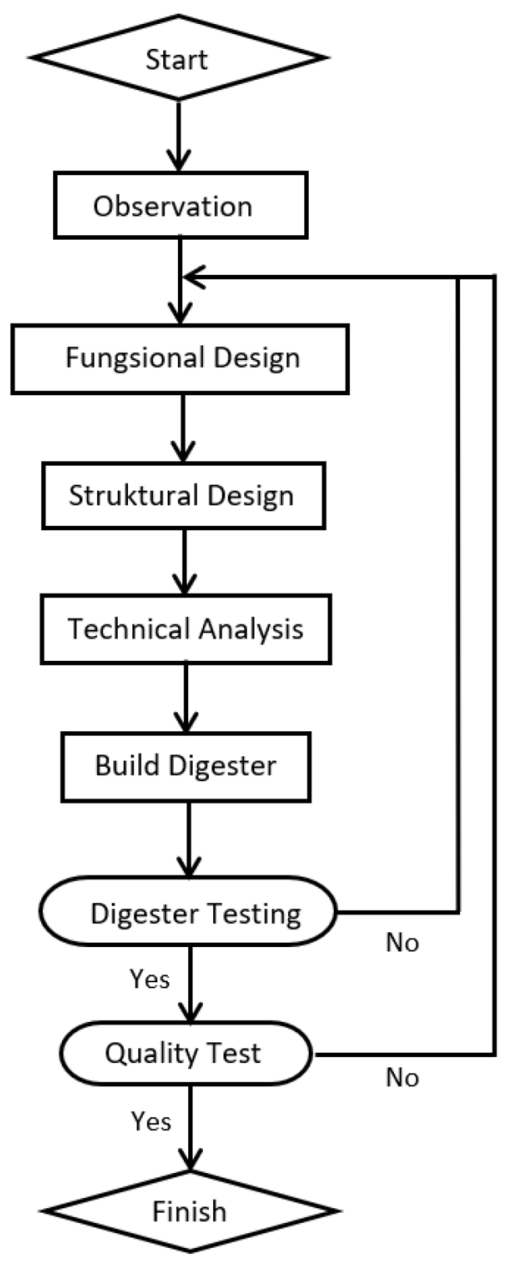

Fig. 1 Flow chart of digester design 
The crushed wastes were converted into slurry by mixing hot water in weight ratio of 1:1. Furthermore, the mixture was made as the object of thermophilic pretreatment.

Preparation of thermophilic bacteria. Consortium of thermophilic bacteria was obtained from organic matter that decomposed in hot springs at Galunggung Volcano in Tasikmalaya District. The inoculants of thermophilic bacteria were cultured in the laboratory at temperatures of $55-60{ }^{\circ} \mathrm{C}$ for 30 days.

\section{Arrangement of treatment}

The aim of the experiment was to test the effect of four waste treatments biogas production and digestate performance. The treatment of fruit waste was varied as A (banana waste), $\mathrm{B}$ (papaya waste), C (banana waste + papaya waste in ratio of 1.5:1), and D (banana waste + papaya waste in ratio of $1: 1)$, respectively.

The experimental design was used in a randomized block design and five treatments were carried out. Data analysis was done by analysis of variance (ANOVA) and Duncan's test (Gomez and Gomez 1984).

\section{Digestate quality testing}

\section{Materials}

Preparation of Ipomoea reptans nursery. Each Ipomoea reptans planting unit consists of 20 plants on soil-growing media in plastic tray size of $30 \mathrm{~cm} \times 30 \mathrm{~cm} \times 5 \mathrm{~cm}$. The experiment had 5 treatments and 5 repetitions, so it took 25 planting units.
Arrangement of treatment. The experiment aimed to test the effectiveness of four digestate as liquid organic fertilizer on the Ipomoea reptans growth. The treatment of digestate was varied as $\mathrm{A}^{\prime}$ (digestate from treatment A), B' (digestate from treatment $\mathrm{B}$ ), $\mathrm{C}^{\prime}$ (digestate from treatment $\mathrm{C}$ ), $\mathrm{D}^{\prime}$ (digestate from treatment $\mathrm{D}$ ), and $\mathrm{E}$ (water without digestate as comparator), respectively.

\section{Experimental set up}

The experimental design was used in a randomized block design and five treatments were carried out. Data analysis was done by analysis of variance (ANOVA) and Duncan's test (Gomez and Gomez 1984).

Variables of response as growth parameters were measured on indicator of (1) length of shoot; and (2) weight of plant biomass. Measurement was taken on a 21-day-old plant.

\section{Results and discussion}

\section{Digester design}

The thermophile biogas digester consists of seven functional components, namely: (1) digester tank; (2) water batch; (3) thermostat; (4) water heater; (5) biogas pipeline; (6) biogas container tank; and (7) digestate and compost container tank.

Figure 2 elucidates structural design of the thermophile biogas digester consisting of: (1) 10-L HDPE jarrycan with length-width of $25-13 \mathrm{~cm}$ and height of $30 \mathrm{~cm}$ as a digestion tank; (2) as the basin water bath used stainless steel drum with a diameter of $56 \mathrm{~cm}$ and a height of $42 \mathrm{~cm}$; (3)
Fig. 2 Structural design of thermophilic biogas digester

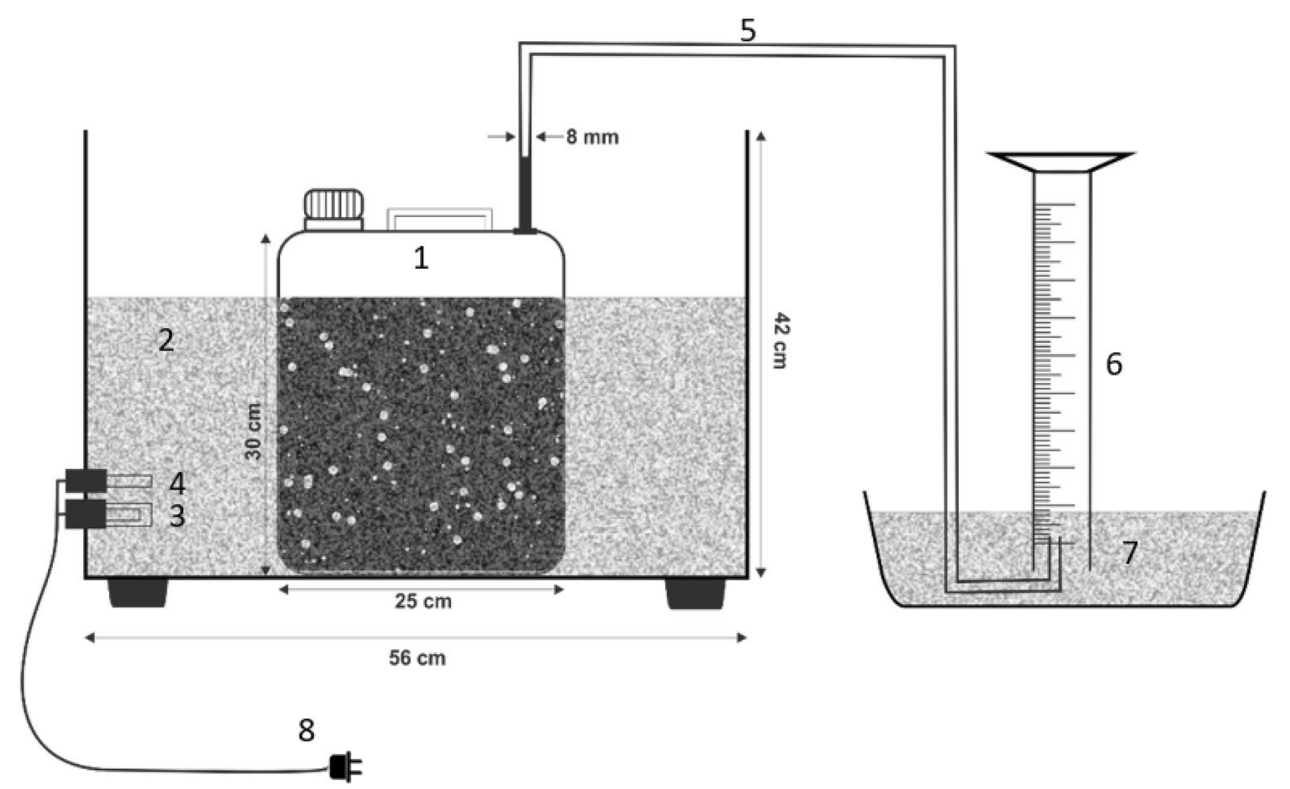


electric heater SG-1103 L232X capacity of $1 \mathrm{~kW}$ and thermostat Ego-241 $\mathrm{T} 150$ range of $10-110{ }^{\circ} \mathrm{C}$ that components maintain the digester in temperature range of $55-60{ }^{\circ} \mathrm{C}$; (4) Weike assembled-thermometer range of $10-100{ }^{\circ} \mathrm{C}$; (5) plastic pipeline with hole diameter of $0.8 \mathrm{~cm}$ as biogas diverter; (6) measuring tube as biogas container; (7) container with sealing water; and (8) AC-electricity power source.

The performance of a biogas digester is determined by many factors, among which are microbial population, acidity $(\mathrm{pH})$, carbon-nitrogen mass ratio ( $\mathrm{C} / \mathrm{N}$ ratio), operating temperature, substrate particle size, organic loading rate, hydraulic retention time, total solids content, and reactor configuration, i.e., batch or continuous, single stage or two stages (Haryanto et al. 2018). Those things explained that variations in design, dimensions, and operational parameters of a digester will effect on its performance.

The effect of stirring, operation temperature, organic loading rate and reactor design on the methane production rate and methane yield was studied. For the same duration of digestion, the unmixed digester produced $20-50 \%$ more methane than mixed system. Two-stage design which separated the soluble components from the solids and treated them separately had more rapid kinetics than one-stage system, producing the target methane potential in one-half the retention time than the one-stage system. The two-stage system degraded $6 \%$ more solids than the single-stage system (Dhoble and Pullammanappalli 2014). The study was intended to understand the biogas production process at mesophilic temperature $\left(37^{\circ} \mathrm{C}\right)$. The organic waste from kitchen was used to make up substrate, which was anaerobically digested in an experimental continues stirred tank reactor (CSTR). Inhibition phase was detected when the graph was plotted for first 60 days and about 28th day, it was inhibited. Simple regression yielded a good predictive model that gave a correlation of 0.995 , despite including the inhibition phase in complete analysis. Such models can also be used to keep check on digestion process for optimization of biogas yield and deciding the substrate feeding rate and concentration on time scale (Ali et al. 2016).

Biogas produced from cow manure in a $25-\mathrm{L}$ semicontinuous digester and working at ambient temperatures turned out that the loading rate affects the yield and productivity of biogas, where the increase in substrate loading rate decreased the production and yield of biogas (Haryanto et al. 2018).

The batch experiment was carried out in a 250-mL Duran bottle as a bioreactor with a working volume of $200 \mathrm{~mL}$ placed in a water bath shaker (100 revolutions per min) under the thermophilic temperature $\left(55 \pm 2{ }^{\circ} \mathrm{C}\right)$. The twostage thermophilic digestion process could effectively enhance biohydrogen and biomethane production, as well as reducing organic waste simultaneously (Wongthanate and Mongkarothai 2018). As found previously, thermophilic bacteria are of great importance in organic matter decomposition during thermophilic composting. No remarkable changes were observed among colonies on agar plates over the first 3 days of the process, suggesting that the thermophilic microflora stabilized soon with no significant succession within this time. Mesophilic fungi were detected only in the initial stages of composting, before quickly diminishing. Thermophilic fungi were not detected at time during the experiments that composting temperatures of $60{ }^{\circ} \mathrm{C}$ or higher are incompatible with the growth of even thermophilic eumycetes (Nakasaki et al. 2005).

\section{Measurement of digester performance}

\section{Biogas production}

The volume of daily biogas yield from the four treatments is shown in Fig. 3. The feedstock of all treatments contain easily hydrolyzed organic compounds such as sugar, fatty acids, and amino acids, which can be quickly converted into biogas and other gases, and peak after two digestive days. Observed after 4 days of digestion, the daily volumes of biogas yield were close to zero, because feedstock was almost completely digested. This result contrasted with previous studies, which concluded that the biogas yield on the 10th day was $7.23 \mathrm{~L}$ in the 36-L digester which operated at a daily temperature of $28.7-29.1^{\circ} \mathrm{C}$. The best biogas productivity was $77.32 \mathrm{~L} / \mathrm{kg}$ VS found at an organic loading rate of $1.31 \mathrm{~g} / \mathrm{L} /$ day (Haryanto et al. 2018). The above research proved that the thermophilic pretreatment process in fruit waste could provide more feedstock for the next process of anaerobic digestion (methanogenesis), so the process runs faster and more biogas and digestate were produced.

The highest total biogas production results in treatment C, followed by treatments A, B and D (Table 1).

Treatment $\mathrm{C}$ has a $\mathrm{C} / \mathrm{N}$ ratio which is more suitable as a substrate for anaerobic digestion process.

Ward et al. (2008) stated that a very strong reason for anaerobic feedstock digestion is adjustment of carbon-nitrogen ratio $(\mathrm{C} / \mathrm{N})$. Microorganisms generally use carbon and nitrogen in a ratio of $25-30: 1$, but $\mathrm{C} / \mathrm{N}$ ratio is often much lower than this ideal.

Subsequent study show that there was an interaction effect between temperature and $\mathrm{C} / \mathrm{N}$ ratio on the performance of anareobic digestion. When the temperature is increased, it is necessary to increase the $\mathrm{C} / \mathrm{N}$ ratio of the substrate, so that the risk of ammonia inhibition is reduced. Increased $\mathrm{C} / \mathrm{N}$ ratio reduces the negative effects of ammonia and maximum methane yield potential is achieved at $\mathrm{C} / \mathrm{N} 25$ and 30 ratios at $35{ }^{\circ} \mathrm{C}$ and $55{ }^{\circ} \mathrm{C}$, respectively (Wang et al. 2014). The efficiency of anaerobic digestion of food waste increased from 69 to $74 \%$, when the $\mathrm{C} / \mathrm{N}$ 
Fig. 3 Graphic of daily biogas production of the treatment $\mathrm{A}$, $\mathrm{B}, \mathrm{C}$, and $\mathrm{D}$

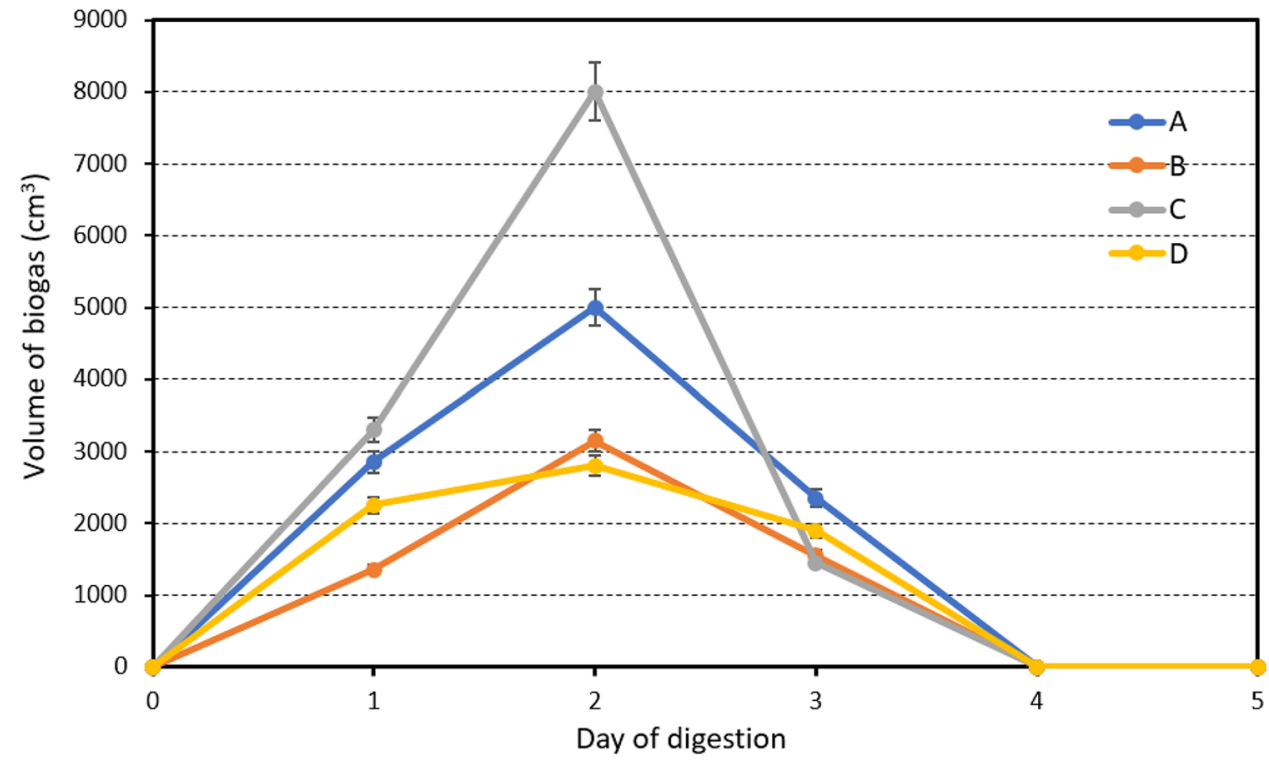

Table 1 Biogas production of each treatment

\begin{tabular}{lrl}
\hline Treatment & \multicolumn{2}{l}{ Volume of biogas $(\mathrm{mL})$} \\
\cline { 2 - 3 } & \multicolumn{1}{l}{ Mean } & Deviation \\
\hline A & $10,200 \mathrm{~b}$ & 255.65 \\
$\mathrm{~B}$ & $6050 \mathrm{a}$ & 128.68 \\
$\mathrm{C}$ & $12,750 \mathrm{c}$ & 372.83 \\
$\mathrm{D}$ & $6950 \mathrm{a}$ & 184.82 \\
\hline
\end{tabular}

Numbers followed by the same letter indicate no significant differences according to the Duncan's multiple range test at a confidence level of $5 \%$

ratio was $17-26$, respectively. The results generally show that increasing the $\mathrm{C} / \mathrm{N}$ ratio of food waste results in better $\mathrm{pH}$ stability and increases methanogenic activity.

Previous research has shown that the generation of thermophilic biohydrogen from food waste was achieved at optimal conditions at initial $\mathrm{pH} 7.0$ and $\mathrm{C} / \mathrm{N} 30$ ratio. Hydrogen-fermented waste can be used as a substrate for the production of thermophilic biomethane, which was obtained optimally at an initial $\mathrm{pH}$ of 7.0 and a $\mathrm{C} / \mathrm{N}$ ratio of 30 . In this optimal condition, COD removal efficiency can be achieved in the range of $70-90 \%$. Therefore, a two-stage process in a controlled system to process organic food waste material at optimal conditions can increase bioenergy production (Wongthanate and Mongkarothai 2018).

The total of biogas production per $8 \mathrm{~L}$ of processed substrate for the 7 days retention time in series was: B $\left(6050 \mathrm{~cm}^{3}\right), \mathrm{D}\left(6950 \mathrm{~cm}^{3}\right), \mathrm{A}\left(10,200 \mathrm{~cm}^{3}\right)$, and C $\left(12,750 \mathrm{~cm}^{3}\right)$. The highest production in $\mathrm{C}$ treatment was due to the substrate condition with the $\mathrm{pH}$ and $\mathrm{C} / \mathrm{N}$ ratio approaching the optimal value. The optimum conditions for acidogenesis and methanogenesis at $\mathrm{pH}$ range from 6.4 to
7.2, while for the anaerobic digestion process in $\mathrm{C} / \mathrm{N}$ range from 20 to 30 (Wang et al. 2014).

Pre-treatment (PT) of active waste sludge (WAS) was optimized by thermochemical treatment at $70{ }^{\circ} \mathrm{C}$ and $0.04 \mathrm{M} \mathrm{NaOH}$ solution for $1 \mathrm{~h}$. The maximum PT efficiency in sludge disintegration can be achieved in combination with heat treatment and low chemical-related costs. Some advantages of the PT were increasing the yield of methane and biogas, causing increased degradation of sludge during anaerobic digestion, the drainage capacity of higher digestible sludge, and reducing the amount of waste to be disposed of in relation to WAS from waste water treatment plants (Nagler et al. 2018).

Referring to the daily and total biogas production, it is proven that single or mixed fruit waste can produce biogas. The biogas production through anaerobic digestion offers significant advantages over other forms of bioenergy production. The digestate allows an accurate dosage and integration in a fertilization plan with a reduced application of additional mineral nitrogen fertilizers (Weiland 2010).

\section{Digestate yield}

As shown in Table 2, papaya waste produced the highest volume of digestate and was followed by decreasing by mixture of banana waste-papaya waste in weight ratio of $1: 1$, banana waste-papaya waste in weight ratio of $1.5: 1$, and banana waste. The difference in the quantity of digestate results was due to the water content of the waste papaya higher than the others. In contrast, the highest weight of dry compost was produced by banana waste and followed by a decreasing by mixture of banana waste-papaya waste (1.5:1), papaya waste, and mixture of banana waste-papaya waste $(1: 1)$. This condition can be explained that the weight 
Table 2 Quantities of digestate and compost yield

\begin{tabular}{|c|c|c|c|c|c|c|}
\hline \multirow[t]{2}{*}{ Treatment } & \multicolumn{2}{|c|}{ Volume of digestate $(\mathrm{mL})$} & \multicolumn{2}{|c|}{ Weight of wet compost ( $g$ ) } & \multicolumn{2}{|c|}{$\begin{array}{l}\text { Weight of dry compost } \\
\text { (g) }\end{array}$} \\
\hline & Mean & Deviation & Mean & Deviation & Mean & Deviation \\
\hline A & 5900 & 101.29 & 1750 & 46.58 & 1420 & 75.763 \\
\hline B & 6800 & 96.75 & 1300 & 95.71 & 1130 & 51.96 \\
\hline $\mathrm{C}$ & 6300 & 118.99 & 1550 & 60.49 & 1337 & 63.86 \\
\hline D & 6500 & 95.29 & 1400 & 39.24 & 1098 & 72.28 \\
\hline
\end{tabular}

of dry compost, as plant solid-biomass was constitutive to the quantity of digestate.

\section{Digestate quality testing}

Table 3 shows that all treatments provide different levels of ground spinach growth than controls. The highest growth was achieved by the treatment of liquid organic fertilizers derived from banana digestate liquid (LD) followed by decrease by digestate from a mixture of banana-papaya (1.5:1), mixture of banana-papaya (1:1), and papaya digestate. The experiment proved that LD's treatment as a liquid organic fertilizer was able to be an adequate supplier of nutrients for ground spinach plans. Digestates are content $\mathrm{pH}, \mathrm{NH}_{3} / \mathrm{NH}_{4}$, and metal elements, mainly $\mathrm{Cu}, \mathrm{Zn}$ and $\mathrm{Mn}$ higher than livestock manures. Digestates may have an $\mathrm{N}$, $\mathrm{P}$ and $\mathrm{K}$ macronutrient composition that was not optimal for plant growth needs, but variations in $\mathrm{P}$ and $\mathrm{K}$ content were within the suitable range for crop production (Sogn et al. 2018).

The anaerobic digestion process results in a mineralization of organically bounded nutrients, in particular nitrogen and in a lowering of the $\mathrm{C} / \mathrm{N}$ ratio. Both effects increase the short-term $\mathrm{N}$ fertilization effect. Due to the improved flow properties, the digestate can penetrate faster in the soil which reduces the risk for nitrogen losses by ammonia emissions. Anaerobic digestion results also in a significant reduction of odors and in a positive change in the composition of odors. Measurements have shown that up to $80 \%$ of the odors in the feedstock can be reduced (Weiland 2010).
Sediment from biogas digester can be used as material for the generation of vermicompos. The vermicomposts are rich in $\mathrm{N}-\mathrm{P}-\mathrm{K}$ nutrients and the $\mathrm{C} / \mathrm{N}$ ratio is below 15 which shows the agronomic role as a soil conditioner and manure. The quality of raw materials determines the physico-chemical characteristics of vermicompost. The results show that vermicompost can be introduced as a technology to convert organic waste into value-added products (Yadav and Garg 2016).

\section{Conclusions}

The biogas digester was performing of thermophilic initial decomposition in its pre-treatment tank. In the pretreatment tank, complex organic compounds, cellulose and hemicellulose were decomposed intensively converted as substrates for anaerobic digestion.

The thermophilic process involved as a pretreatment can shorten digestion time to 3 days. As feedstock, each $4-\mathrm{kg}$ banana waste, papaya waste, mix of banana-papaya waste in weight ratio of $1: 1$, and mix of banana-papaya waste in weight ratio of $1.5: 1$ produced biogas of $10,200 \mathrm{~cm}^{3}$, $6050 \mathrm{~cm}^{3}, 12,750 \mathrm{~cm}^{3}$, and $6950 \mathrm{~cm}^{3}$, respectively. Furthermore, digestate of $5900 \mathrm{~mL}, 6800 \mathrm{~mL}, 6300 \mathrm{~mL}$, and $6500 \mathrm{~mL}$ was produced; also dry compost of $1420 \mathrm{~g}, 1130 \mathrm{~g}$, $1337 \mathrm{~g}$ and $1098.58 \mathrm{~g}$ was produced, respectively.
Table 3 Effect of liquid digestate (LD) on Ipomoea reptans growth at 21 days old

\begin{tabular}{|c|c|c|c|c|}
\hline \multirow[t]{2}{*}{ Treatment } & \multicolumn{2}{|c|}{ Height of plant shoot (cm) } & \multicolumn{2}{|c|}{$\begin{array}{l}\text { Weight of plant biomass } \\
\text { (g) }\end{array}$} \\
\hline & Mean & Deviation & Mean & Deviation \\
\hline $\mathrm{A}^{\prime}$ (banana waste LD) & $18.86 \mathrm{~d}$ & 0.58 & $44.97 \mathrm{~d}$ & 0.89 \\
\hline B' (papaya waste LD) & $15.61 \mathrm{~b}$ & 0.61 & $33.50 \mathrm{~b}$ & 0.74 \\
\hline $\mathrm{C}^{\prime}$ (banana + papaya waste LD 1:1) & $15.76 \mathrm{~b}$ & 0.39 & $35.67 \mathrm{~b}$ & 1.25 \\
\hline $\mathrm{D}^{\prime}$ (banana + papaya waste LD $1,5: 1$ ) & $18.41 \mathrm{c}$ & 0.59 & $38.78 \mathrm{c}$ & 0.99 \\
\hline E (water without LD as control) & $14.32 \mathrm{a}$ & 0.32 & $26.92 \mathrm{a}$ & 1.05 \\
\hline
\end{tabular}

Numbers followed by the same letter indicate no significant differences according to the Duncan's multiple range test at a confidence level of 5\% 
Acknowledgements The researchers would like to thank for funding support from the Directorate General of Research and Development Strengthening of the Ministry of Research, Technology and Higher Education of the Republic of Indonesia according to Grant number 050/UN58.21/LT/2018.

Open Access This article is distributed under the terms of the Creative Commons Attribution 4.0 International License (http://creativeco mmons.org/licenses/by/4.0/), which permits unrestricted use, distribution, and reproduction in any medium, provided you give appropriate credit to the original author(s) and the source, provide a link to the Creative Commons license, and indicate if changes were made.

\section{References}

Ali A, Rundong L, Shah F, Mahar RB, Wajidljaz MS, Muquee M (2016) Predictive modeling of biogas production from anaerobic digestion of mixed kitchen waste at mesophilic temperature. Int J Waste Resour 6:1-4. https://doi.org/10.4172/2252-5211.1000230

Dhoble AS, Pullammanappalli PC (2014) Design and operation of an anaerobic digester for waste management and fuel generation during long term lunar mission. Adv Space Res 54:1502-1512. https ://doi.org/10.1016/j.asr.2014.06.029

Gomes E, Souza AR, Ladino GO, Silva R, Oliviera TB, Rodrigues A (2016) Applications and benefits of thermophilic microorganisms and their enzymes for industrial biotechnology. In: Schmoll M, Dattenbök C (Eds) Gene expression systems in fungi: advancement and applications. Springer Int Pub, Cham, pp 459-492. https ://doi.org/10.1007/978-3-319-27951-0

Gomez KA, Gomez AA (1984) Statistical procedures for agricultural research. Wiley, Inc UI Press, Jakarta

Haryanto A, Triyono S, Wicaksono NH (2018) Effect of hydraulic retention time on biogas production from cow dung in a semi continuous anaerobic digester. Int J Renew Energy Dev 7:93-100. https://doi.org/10.14710/ijred.7.2.93-100

Howard TJ, Culley SJ, Dekoninck EA (2008) Describing the creative design process by the integration of engineering design and cognitive psychology literature. Des Stud 29:160-180. https://doi. org/10.1016/j.destud.2008.01.001

Indonesian Goverment Regulation Number 81 of 2012 (2012) on Household and similar waste management. Available in: https:// peraturan.bpk.go.id/Home/Detail/5295/pp-no-81-tahun-2012

Indonesian National Legislation Number 18 of 2008 (2008) on Waste management. Available in: https://peraturan.bpk.go.id/Home/ Detail/39067/uu-no-18-tahun-2008
Nagler M, Aichinger P, Kuprian M, Pumpel T, Insam H, Ebne C (2018) A case study for a cost-benefit-based, stepwise optimization of thermo-chemical WAS pre-treatment for anaerobic digestion. J Mater Cycles Waste Manag 20:266-273. https://doi.org/10.1007/ s10163-016-0577-x

Nakasaki K, Nag K, Karita S (2005) Microbial succession associated with organic matter decomposition during thermophilic composting of organic waste. Waste Manag Res 23:48-56. https://doi. org/10.1177/0734242X05049771

Rahmat B, Setiasih IS, Kastaman R (2013) Biodiesel reactor design with glycerol separation to increase biodiesel production yield. Makara J Sci 17:11-16. https://doi.org/10.7454/mst.v17i1.1921

Salemdeeb R, Daina MB, Reynolds C, Al-Tabbaa A (2018) An environmental evaluation of food waste downstream management options: a hybrid LCA approach. Int J Recycl Org Waste Agric 7:217-229. https://doi.org/10.1007/s40093-018-0208-8

Sogn TA, Dragicevic I, Linjordet R, Krogstad T, Eijsink VGH, EichGreatorex S (2018) Recycling of biogas digestates in plant production: NPK fertilizer value and risk of leaching. Int J Recycl Org Waste Agric 7:49-58. https://doi.org/10.1007/s40093-017-0188-0

Sudharmaidevi CR, Thampatti KCM, Saifudeen N (2017) Rapid production of organic fertilizer from degradable waste by thermochemical processing. Int J Recycl Org Waste Agric 6:1-11. https ://doi.org/10.1007/s40093-016-0147-1

Wang X, Lu X, Li F, Yang G (2014) Effects of temperature and carbon-nitrogen $(\mathrm{C} / \mathrm{N})$ ratio on the performance of anaerobic codigestion of dairy manure, chicken manure and rice straw: focusing on ammonia inhibition. Pub Libr Sci J 9:e97265. https://doi. org/10.1371/journal.pone.0097265

Ward AJ, Hobbs PJ, Holliman PJ, Jones DL (2008) Optimisation of the anaerobic digestion of agricultural resources. Bioresour Technol 99:7928-7940. https://doi.org/10.1016/j.biortech.2008.02.044

Weiland P (2010) Biogas production: current state and perspectives. Appl Microbiol Biotechnol 85:849-860. https://doi.org/10.1007/ s00253-009-2246-7

Wongthanate J, Mongkarothai K (2018) Enhanced thermophilic bioenergy production from food waste by a two-stage fermentation process. Int J Recycl Org Waste Agric 7:109-116. https://doi. org/10.1007/s40093-018-0196-8

Yadav A, Garg VK (2016) Vermiconversion of biogas plant slurry and parthenium weed mixture to manure. Int J Recycl Org Waste Agric 5:301-309. https://doi.org/10.1007/s40093-016-0140-8

Publisher's Note Springer Nature remains neutral with regard to jurisdictional claims in published maps and institutional affiliations. 